\title{
EFEKTIVITAS MINERAL KALSIUM TERHADAP PERTUMBUHAN YUWANA UDANG GALAH (Macrobrachium rosenbergii)
}

\author{
Lies Emmawati Hadie, Wartono Hadie, dan Tri Heru Prihadi \\ Pusat Riset Perikanan Budidaya \\ Jl. Ragunan 20, Pasar Minggu, Jakarta Selatan 12540 \\ E-mail:ema_hadi@yahoo.com
}

Naskah diterima: 6 September 2008; Diterima publikasi: 17 April 2009

\begin{abstract}
ABSTRAK
Pertumbuhan udang galah dibatasi oleh kulitnya yang bersifat tidak elastis, karena terdiri atas khitin. Agar udang galah tumbuh dengan baik, maka harus ada unsur mineral dalam pakannya. Salah satu mineral yang bersifat esensial adalah mineral kalsium. Kalsium mempunyai fungsi dalam pembentukan tulang, jaringan lunak, proses regulasi dalam tubuh, dan menjaga keseimbangan asam basa. Oleh karena peran penting dari kalsium tersebut, maka dilakukan penelitian mengenai efek mineral kalsium dalam ransum pakan udang galah terhadap pertumbuhannya. Hewan uji yang digunakan pada penelitian ini adalah yuwana udang galah dengan kisaran bobot 56,0 $\pm 3,0 \mathrm{mg}$. Rancangan penelitian menggunakan Rancangan Acak Lengkap dengan perlakuan yang diterapkan adalah kalsium 1,0\%; 3,0\%; 5,0\%; 7,0\%; dan 0,0\% sebagai kontrol. Setiap perlakuan mendapat 3 ulangan. Hasil penelitian ini menunjukkan bahwa kadar kalsium dalam ransum pakan sangat mempengaruhi laju pertumbuhan harian udang galah $(P<0,05)$. Kadar kalsium yang optimal dalam ransum pakan udang galah adalah sebesar $3,46 \%$.
\end{abstract}

KATA KUNCI: mineral, kalsium, pertumbuhan, udang galah

ABSTRACT: Effectiveness of calcium mineral on the growth of juvenile of giant freshwater prawn (Macrobrachium rosenbergii). By: Lies Emmawati Hadie, Wartono Hadie, and Tri Heru Prihadi

The growth of giant prawn is limited by a non elastic material called chitin, which is a limiting factor in its growth. Feed containing mineral is needed to improve its growth. One of the essential minerals is calcium. The function of calcium is essential in bone and soft tissue formations, acid balancing, and regulation processes in the body. Because of its benefits, the research on the calcium effect on giant prawn was conducted. The aims of this study was to know the effect of calcium on the growth rate of giant prawn juvenile. Test animals were juveniles of giant prawn with average weight of $56.0 \pm 3.0 \mathrm{mg}$. Research design employed complete randomized design with five calcium mineral treatments as follows: $1.0 \%, 3.0 \%, 5.0 \%, 7.0 \%$, and $0.0 \%$ as control. Each treatment has three replications. The result showed that calcium affected the daily growth rate of giant prawn $(P<0.05)$. The calcium dosage of $3.46 \%$ is the optimum level for giant prawn juvenile.

KEYWORDS: mineral, growth, giant prawn 


\section{PENDAHULUAN}

Pada dasarnya pertumbuhan udang terdiri atas serangkaian proses moulting. Khususnya pada tahap post-moult terjadi proses pengerasan kulit melalui pengendapan kalsium pada kulit udang. Kebutuhan kalsium dapat dicukupi dari pakan dan dari lingkungan. Dengan demikian peran kalsium sangat dominan dalam proses pengerasan kulit udang, maka dalam fase pengerasan tersebut dibutuhkan kalsium yang cukup tinggi (Greenway, 1974; Frence,1983). Pada saat proses pre-moult kalsium yang diserap kemudian disimpan dalam gastrolit, lalu masuk ke dalam saluran pencernaan dan selanjutnya ke hemolimfa. Setelah proses moulting selesai, kalsium yang berada di hemolimfa digunakan untuk pengerasan eksoskeleton. Kalsium yang berasal dari hemolimfa hanya memenuhi $10 \%$ dari kebutuhan kalsium, dan sisanya diperoleh dari kalsium di lingkungan perairan (Greenway, 1974). Oleh karena itu, terdapat hubungan yang positif antara kalsium pada hemolimfa dan kadar kalsium di lingkungan (Adegboye, 1983 dalam Zaidy, 2007).

Kalsium secara aktif ditranspor oleh selsel usus, dan besarnya aktivitas transpor kalsium dipengaruhi oleh beberapa faktor antara lain bagian dari usus, zat-zat nutrisi serta status hormon. Kalsium juga dapat diabsorpsi melalui mekanisme ketidakjenuhan (non saturable mechanism) yang tergantung pada vitamin $\mathrm{D}$ dan ditandai oleh suatu transfer yang bersifat difusi. Absorpsi secara aktif diatur oleh suatu sistem yang disebut gate keeper mechanism yang mengatur intake dan output dari kalsium dari makanan ke dalam dan diekskresi oleh tubuh. Kecepatan ekskresi meningkat seiring dengan menurunnya masukan kalsium dari makanan, dan juga dengan meningkatnya kebutuhan akan mineral tersebut selama periode pertumbuhan (Piliang, 2000).

Penelitian Davis et al. (1992) menunjukkan bahwa dalam ransum pakan udang perlu mengandung mineral, karena mineral tersebut memiliki peran yang penting dalam pertumbuhan udang. Demikian pula menurut Kompiang (1989) bahwa dalam kondisi netral yaitu $\mathrm{pH}$ 5,0-7,0 umumnya mineral kalsium dalam pakan udang yang digunakan dalam bentuk senyawa seperti kalsium karbonat, trikalsium, dan dikalsium fosfat.
Penelitian mengenai fungsi mineral yang esensial dalam ransum pakan udang Penaeus vannamei menunjukkan pentingnya mineral seperti $\mathrm{Mg}, \mathrm{Mn}, \mathrm{Fe}, \mathrm{Zn}$, dan Cu. Ransum pakan udang vanamei yang tidak menggunakan mineral-mineral tersebut, ternyata mengalami penurunan proses mineralisasi. Hal ini terbukti berdasarkan hasil analisis mineral pada hepatopancreas dan carapace udang vanamei (Davis et al., 1992).

Udang vanamei juga membutuhkan fosfor untuk pertumbuhannya, dan kadar fosfor yang sesuai untuk udang tersebut adalah dalam bentuk kalsium fosfat monobasik pada level 1,33\%-1,7\% (Pan et al., 2006).

Oleh karena peran penting dari kalsium tersebut, maka dilakukan penelitian mengenai efektivitas mineral kalsium dalam ransum pakan udang galah terhadap pertumbuhannya.

\section{BAHAN DAN METODE}

\section{Bahan}

Hewan uji yang digunakan dalam penelitian ini adalah yuwana udang galah berukuran $56,0 \pm 3,0 \mathrm{mg}$ dan panjang total berkisar 1,9 $9 \pm$ $0,05 \mathrm{~cm}$. Hewan uji dipelihara di dalam bak beton berukuran $60 \mathrm{~cm} \times 60 \mathrm{~cm}$ sejumlah 15 buah yang dilengkapi dengan sistem aerasi dan tinggi air dalam bak adalah $35 \mathrm{~cm}$. Padat tebar yuwana udang galah untuk setiap bak adalah 20 ekor dan telah diaklimatisasi selama 24 jam sebelum perlakuan. Pakan diberikan kepada udang sebanyak 3 kali sehari dengan tingkat ransum harian sebesar $10 \%$ dari bobot bio-massa. Perubahan jumlah pakan yang diberikan dilakukan setiap 7 hari sekali sesuai dengan hasil pengamatan bobot udang.

Dalam penelitian ini pertumbuhan udang diamati dengan menimbang bobot tubuh dengan tujuan untuk menghitung laju pertumbuhan harian dan konversi pakan. Pengamatan pertumbuhan dilakukan terhadap jumlah total individu dengan $\mathrm{N}=20$. Pengamatan ini dilakukan setiap seminggu sekali.

Pengamatan suhu air dilakukan setiap hari. Pengamatan kadar oksigen, $\mathrm{pH}$, alkalinitas, amonia, dan nitrit dilakukan sebanyak tiga kali yaitu pada awal, pertengahan, dan akhir penelitian yang dilaksanakan pada pukul 08.00 pagi. Penelitian berlangsung selama 12 minggu. 


\section{Metode}

Dalam penelitian ini digunakan Rancangan Acak Lengkap dengan perlakuan adalah penambahan jumlah kadar kalsium karbonat yang terdiri atas 5 perlakuan yaitu 1,0\%; 3,0\%; 5,0\%; 7,0\%; dan 0,0\% sebagai kontrol. Setiap perlakuan mendapat 3 ulangan. Perlakuan kalsium diberikan dalam bentuk penambahan $\mathrm{CaCO}_{3}$ pada ransum pakan dengan komposisi serta analisis proksimat disajikan pada Tabel 1.

Pengolahan data menggunakan analisis ragam dengan tingkat kepercayaan 95\% untuk mengetahui ada tidaknya pengaruh penambahan mineral kalsium terhadap pertumbuhan udang galah. Apabila berdasarkan analisis ragam diperoleh hasil yang menunjukkan adanya perbedaan yang nyata, maka dilakukan Uji Beda Nyata Terkecil pada taraf kepercayaan 95\% (Yitnosumarto, 1993).
Dalam mengevaluasi hasil penelitian digunakan rumus sebagai berikut:

\section{Sintasan (Zonneveld et al., 1991)}

Kelangsungan organisme yang dibudidayakan dihitung dengan persamaan:

$$
\mathrm{S}=\frac{\mathrm{N}_{\mathrm{t}}}{\mathrm{N}_{\mathrm{o}}} \times 100 \%
$$

di mana:

$S=$ Sintasan

$\mathrm{N}_{\mathrm{t}}=$ Jumlah udang pada akhir penelitian (ekor)

$\mathrm{N}_{\mathrm{o}}$ = Jumlah udang pada awal penelitian (ekor)

\section{Laju pertumbuhan harian individu}

Dihitung berdasarkan rumus dari National Research Council (1983):

$$
\sigma=\sqrt[t]{\frac{W_{t}}{W_{o}}}-1 \times 100 \%
$$

Tabel 1. Komposisi dan analisis proksimat ransum pakan percobaan

\begin{tabular}{|c|c|c|c|c|c|}
\hline \multirow{2}{*}{$\begin{array}{c}\text { Bahan } \\
\text { Ingredient }\end{array}$} & \multirow{2}{*}{$\begin{array}{r}\begin{array}{r}\text { Dosis } \\
\text { Dosage }\end{array} \\
100 \%\end{array}$} & \multirow{2}{*}{$\begin{array}{c}\text { Kalsium karbo nat } \\
\text { Calcium carbonat }\end{array}$} & \multicolumn{3}{|c|}{$\left(\mathrm{CaCO}_{3}\right)$} \\
\hline & & & $5.00 \%$ & $7.00 \%$ & Kontrol \\
\hline Tepung ikan (Fish meal ) (\%) & 30 & 30 & 30 & 30 & 30 \\
\hline Tepung jagung ( Corn meal ) (\%) & 17 & 17 & 17 & 17 & 17 \\
\hline Tepung terigu (Wheat meal ) (\%) & 20 & 20 & 20 & 20 & 20 \\
\hline Dedak halus (Rice brand ) (\%) & 10 & 10 & 10 & 10 & 10 \\
\hline Bungkil kelapa (Cake of pressed coconut ) & 16 & 14 & 12 & 10 & 17 \\
\hline Bungkil kedelai (Cake of pressed soy-bean ) & 4 & 4 & 4 & 4 & 4 \\
\hline Vitamin+mineral (Vitamin-mineral mix ) & 2 & 2 & 2 & 2 & 2 \\
\hline Kalsium karbonat $/ \mathrm{CaCO}_{3}($ Calcium carbonat $)(\%)$ & 1 & 3 & 5 & 7 & 0 \\
\hline \multicolumn{6}{|l|}{ Analisis proksimat (Proximat analysis ) } \\
\hline Protein kasar (Crude protein ) (\%) & 36.72 & 37.41 & 36.48 & 36.96 & 36.73 \\
\hline Lemak kasar (Crude lipid ) (\%) & 7.56 & 7.79 & 6.97 & 6.98 & 6.82 \\
\hline Serat kasar (Fibre ) (\%) & 198 & 187 & 2.03 & 194 & 198 \\
\hline Abu (Ash) (\%) & 9.46 & 10.55 & 12.5 & 14.53 & 7.07 \\
\hline \multirow[t]{2}{*}{ NFE (\%) } & 44.28 & 42.38 & 42.02 & 39.59 & 47.40 \\
\hline & 100 & 100 & 100 & 100 & 100 \\
\hline
\end{tabular}

Table 1. Composition and proximat analysis of experimental diets

Vitamin mix: Vit.A(60.000 IU/g); vit.D3 (12.000 IU/g); vit.E (120 mg/g); vit. K3 (12.5 mg/g); vit.B1 (10 $\mathrm{mg} / \mathrm{g}) ;$ vit.B2 (25 mg/g); vit.B6 (10 mg/g); vit.B12 $(0.1 \mathrm{mg} / \mathrm{g}) ; \mathrm{vit} . C(150 \mathrm{mg} / \mathrm{g}) ;$ folic acid $(5 \mathrm{mg} / \mathrm{g})$; nicotinic acid $(60 \mathrm{mg} / \mathrm{g}) ;$ pantothenate acid $(50 \mathrm{mg} / \mathrm{g}) ;$ methionin $(50 \mathrm{mg} / \mathrm{g}) ;$ biotin $(0.125 \mathrm{mg} / \mathrm{g})$

Mineral mix : Calcium (32.5\%); phosphor (10\%); iron (6mg/g); manganese ( $4 \mathrm{mg} / \mathrm{g})$; iodine $(0.075 \mathrm{mg} / \mathrm{g})$; copper $(0.3 \mathrm{mg} / \mathrm{g}) ; \operatorname{Zinc}(3.75 \mathrm{mg} / \mathrm{g})$ 
di mana:

$\sigma=$ Laju pertumbuhan harian

$\mathrm{w}_{\mathrm{t}}=$ Bobot akhir rata-rata hewan uji (g)

$\mathrm{w}_{\mathrm{o}}=$ Bobot awal rata-rata hewan uji (g)

$\mathrm{t}=$ Lamanya penelitian (hari)

\section{Konversi Pakan}

Menurut National Research Council (1983), konversi pakan suatu organisme yang dibudidayakan dapat dengan rumus:

$$
K=\frac{F}{\left(W_{t}+D\right)-W_{0}}
$$

di mana:

$\mathrm{K}=$ Konversi pakan

$\mathrm{F}$ = Jumlah total pakan yang diberikan selama penelitian (gram)

$\mathrm{W}_{\mathrm{t}}=$ Bobot rata-rata individu pada akhir penelitian (gram)

$\mathrm{W}_{0}=$ Bobot rata-rata pada awal penelitian (gram)

$\mathrm{D}$ = Bobot individu yang mati pada waktu penelitian (gram)

\section{HASIL DAN BAHASAN}

Berdasarkan penelitian yang telah dilakukan diperoleh hasil berkaitan dengan pertumbuhan harian udang galah seperti yang tertera pada Tabel 2 .

Hasil penelitian ini menunjukkan bahwa penggunaan kalsium dalam kadar yang berbeda berpengaruh terhadap laju pertumbuhan harian udang galah. Laju pertumbuhan harian dari udang dengan perlakuan kalsium 3,0\% menunjukkan angka tertinggi, kemudian diikuti oleh perlakuan kalsium 5,0\%, kontrol, perlakuan kalsium 1,0\% dan perlakuan kalsium 7,0\% (Tabel 1).

Menurut penjelasan dari Hepher (1988), Davis et al. (2005), Piliang (2000) kalsium memberikan pengaruh terhadap pertumbuhan, karena kalsium merupakan mineral yang berperan dalam proses metabolisme tubuh dalam hal mengatur permeabilitas membran sel dan mengatur masukan zat-zat nutrisi oleh sel. Apabila jumlah kalsium dalam pakan terpenuhi, maka proses metabolisme dalam tubuh tidak akan terganggu. Namun jika ada kekurangan atau kelebihan kadar mineral dalam pakan, maka akan menyebabkan lambatnya pertumbuhan udang (Shiau \& Hsieh, 2001; Cheng et al., 2005).

Pertumbuhan udang galah terjadi dengan melalui serangkaian proses moulting secara periodik. Exoskeleton yang lama akan lepas dan diganti dengan exoskeleton yang baru. Kemudian proses ini dikuti dengan pertumbuhan atau penambahan bobot udang. Dalam siklus moulting terbagi dalam empat tahapan yaitu post-moult, inter-moult, premoult, dan moulting. Pada tahap post-moult terjadi pengerasan exoskeleton yang baru terbentuk dari kalsium dan mineral lainnya. Tahap inter-moult yang merupakan tahap peralihan, dan penyerapan air terjadi selama proses ecdysis. Kemudian air yang diserap masuk ke dalam jaringan, dan diperkaya dengan bahan-bahan organik dan cadangan mineral, sehingga menghasilkan pertumbuhan udang. Tahapan berikutnya adalah pre-moult, kalsium diabsorbsi kembali dari kulit yang lama untuk memperbesar sel-sel epidermal.

Tabel 2. Laju pertumbuhan harian (\%) yuwana udang galah selama 12 minggu masa pemeliharaan

Table 2. Daily growth rate (\%) of juvenile of giant prawn after 12 weeks of rearing period

\begin{tabular}{lcccc}
\hline $\begin{array}{c}\text { Perlakuan } \\
\text { Treatment }\end{array}$ & \multicolumn{4}{c}{$\begin{array}{c}\text { Laju pert umbuhan } \\
\text { Daily }\end{array}$} \\
\cline { 2 - 4 } & $\mathbf{1}$ & 2 & 3 & \\
\hline $1.00 \%$ & 2.9 & 2.9 & 2.8 & $2.86^{\mathrm{a}}$ \\
$3.00 \%$ & 3.1 & 3.2 & 3.4 & $3.23^{\mathrm{b}}$ \\
$5.00 \%$ & 3.1 & 3.3 & 3 & $3.13^{\mathrm{b}}$ \\
$7.00 \%$ & 2.7 & 2.8 & 2.8 & $2.76^{\mathrm{a}}$ \\
\hline Kont rol (Control) & $\mathbf{2 . 8}$ & $\mathbf{2 . 9}$ & $\mathbf{2 . 8}$ & $\mathbf{2 . 9 0 ^ { \mathrm { a } }}$ \\
\hline
\end{tabular}

Nilai pada kolom dengan huruf yang sama tidak berbeda nyata $(P>0,05)$

$V a l u e s$ in the same column with the same letter are not significantly different $(P>0.05)$ 
Tahapan terakhir adalah moulting yaitu exoskeleton yang lama terlepas dan diganti dengan exoskeleton baru yang masih lunak. Selama proses moulting berlangsung, maka tingkat kalsium berfluktuasi. Hal ini menunjukkan fungsi penting dari mineral ini dalam pembentukan exoskeleton. Fungsi utama kalsium adalah pada pembentukan kulit udang yang terdiri atas khitin (Saravanan, 2008). Menurut Soeharso (1999), kadar kalsium dalam kutikula udang galah mencapai $26,3 \%$ 49,3\% dan kadar Mg sebesar 0,83\%-1,04\%. Jika kadar kalsium rendah maka kadar Mg akan tinggi, dan rentang variasi kandungan mineral yang lebar terjadi selama periode moulting. Hal ini sejalan dengan metabolisme dalam proses pertumbuhan udang selama periode moulting berlangsung. Hasil analisis termal menunjukkan bahwa senyawa kalsium dalam kutikula udang galah terutama berbentuk kalsium fosfat dan kalsium karbonat.

Fungsi kalsium yang penting lainnya adalah membantu mekanisme absorpsi vitamin $B_{12}$ dari saluran pencernaan makanan dan absorpsi vitamin pada membran sel. Kalsium juga berperan dalam membantu menyalurkan rangsangan-rangsangan syaraf dari satu sel kepada sel lainnya dengan cara mengatur pembentukan acetylcholine (Piliang, 2000).

Berdasarkan analisis ragam menunjukkan bahwa adanya perbedaan yang nyata dari penambahan kalsium terhadap laju pertumbuhan harian udang $(P<0,05)$. Laju pertumbuhan harian relatif lambat pada udang yang diberi perlakuan dengan kadar di bawah $3,0 \%$ dan $7,0 \%$. Pertumbuhan yang lambat ini kemungkinan disebabkan oleh mekanisme absorpsi vitamin $\mathrm{B}_{12}$ pada membran sel yang relatif lambat, sehingga efisiensi penggunaan pakan juga akan menurun. Demikian pula kepekaan dan aktivitas serta daya tahan tubuh menjadi menurun. Menurut Zaidy (2007), bila terjadi kekurangan kalsium maka dapat mengakibatkan pelunakan dari kulit udang. Hal ini dapat menyebabkan proses pergantian kulit udang terganggu, sehingga udang tidak dapat tumbuh dengan optimal.

Laju pertumbuhan harian udang dengan perlakuan kadar kalsium dalam pakan lebih dari $5,0 \%$ juga mengalami pertumbuhan yang relatif lambat dibandingkan dengan udang yang diberi kalsium dengan dosis $3,0 \%$ dan $5,0 \%$. Kondisi ini disebabkan oleh terjadinya proses hiperkalsemia, karena aborbsi kalsium yang berlebihan dan menyebabkan terjadinya kerusakan pada ginjal. Pertumbuhan udang menjadi lambat sehingga berdampak terhadap penurunan efisiensi pakan. Hal ini sesuai dengan pendapat Baron (1990) jika kadar kalsium berlebihan dosisnya maka akan terjadi gangguan dalam pertumbuhan. Kondisi ini juga terlihat nyata pada udang yang diberi perlakuan dalam kadar kalsium 7,0\% yang tumbuh lebih lambat dibandingkan dengan perlakuan lainnya.

Hasil yang serupa juga dijumpai pada udang vanamei yang dalam ransum pakannya ditambahkan kalsium fosfat. Hasil penelitian Pan et al. (2006) menunjukkan bahwa penambahan kalsium fosfat sebesar 1,33\% dalam ransum pakan ternyata meningkatkan pertumbuhan udang vanamei dan meningkatkan efisiensi pakan.

Hubungan laju pertumbuhan udang galah pada perlakuan penambahan kalsium disajikan pada Gambar 1.

Laju pertumbuhan harian udang memenuhi syarat persamaan regresi kuadratik yaitu $Y=2,8153+0,2166 x-0,0317 x^{2}$ dengan nilai $r=0,89$. Fungsi ini menunjukkan bahwa penambahan kalsium dalam ransum pakan tidak selalu diikuti oleh laju pertumbuhan harian yang meningkat. Interpretasi dari fungsi ini menunjukkan bahwa kadar optimum penambahan kalsium dalam ransum pakan adalah sebesar $3,46 \%$.

Nilai konversi pakan yang dicapai dari penelitian ini dapat dilihat pada Tabel 3. Nilai konversi pakan yang paling rendah terdapat pada perlakuan kadar kalsium 3,0\% dan 5,0\%. Ini menunjukkan bahwa kadar kalsium sebesar $3,0 \%$ sudah cukup memenuhi kebutuhan guna mendukung pertumbuhan udang galah. Konversi pakan berbanding terbalik dengan pertambahan bobot tubuh. Dengan demikian semakin rendah konversi pakan berarti semakin efisien udang memanfaatkan pakan untuk mendukung pertumbuhannya. Dari pengamatan konversi pakan maka perlakuan dengan kadar kalsium 3,0\% dan 5,0\% menunjukkan hasil yang lebih baik dibandingkan dengan perlakuan lainnya.

Hasil analisis ragam menunjukkan bahwa penambahan kalsium dalam ransum sangat nyata mempengaruhi nilai konversi pakan $(P<0,05)$. Analisis lanjut nyata memperlihatkan bahwa kadar kalsium 3,0\% dan 5,0\% memberikan nilai konversi pakan nyata lebih baik dibandingkan dengan perlakuan lainnya 


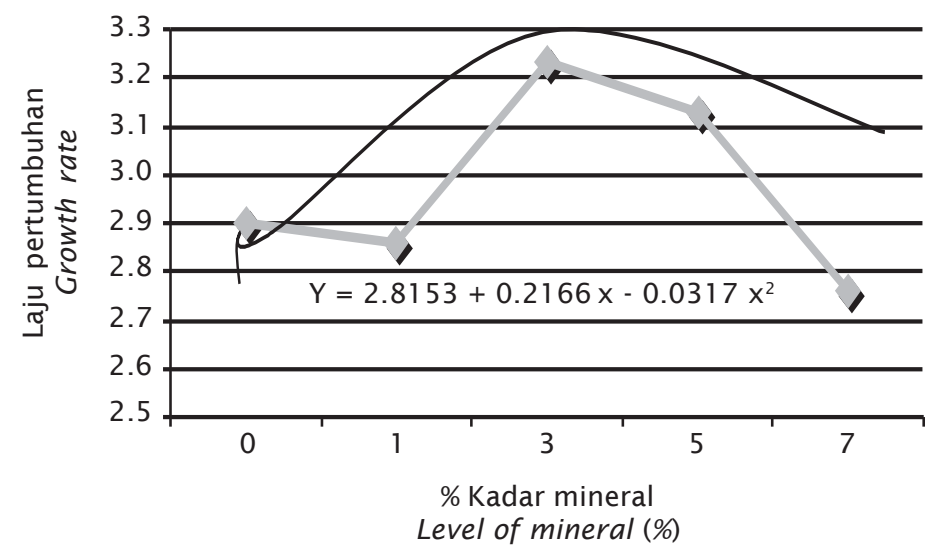

Gambar 1. Kurva respons laju pertumbuhan harian (\%) udang galah dengan perlakuan penambahan kalsium karbonat $1,0 \%$; 3,0\%; 5,0\%; 7,0\% dan kontrol

Figure 1. Response curve of daily growth rate (\%) of giant prawn to calcium carbonate treatments at levels of $1.0 \%$, $3.0 \%, 5.0 \%, 7.0 \%$, and control

Tabel 3. Nilai konversi pakan yang dicapai pada setiap perlakuan dengan kadar kalsium karbonat 1,0\%; 3,0\%; 5,0\%; 7,0\%; dan kontrol

Table 3. Feed conversion ratio of each treatment with dosages of calcium carbonate of $1.0 \%, 3.0 \%, 5.0 \%, 7.0 \%$, and control

\begin{tabular}{lcccc}
\hline $\begin{array}{c}\text { Perlakuan } \\
\text { Treatment }\end{array}$ & \multicolumn{2}{c}{ Konversi pakan (Feed conversion) } & $\begin{array}{c}\text { Rata-rata } \\
\text { Average }\end{array}$ \\
\cline { 2 - 4 } & $\mathbf{1}$ & $\mathbf{2}$ & $\mathbf{3}$ & \\
\hline $1.00 \%$ & 3.0 & 3.3 & 3.4 & $3.2^{\mathrm{a}}$ \\
$3.00 \%$ & 2.9 & 3.0 & 2.9 & $2.9^{\mathrm{b}}$ \\
$5.00 \%$ & 2.9 & 2.8 & 3.1 & $2.9^{\mathrm{b}}$ \\
$7.00 \%$ & 3.4 & 3.3 & 3.4 & $3.4^{\mathrm{a}}$ \\
Kontrol (Control) & 3.0 & 3.2 & 3.3 & $3.2^{\mathrm{a}}$ \\
\hline
\end{tabular}

Nilai pada kolom dengan huruf yang sama tidak berbeda nyata $(P>0,05)$

Values in the same column with the same letter are not significantly different $(P>0.05)$

$(\mathrm{P}<0,05)$, sedangkan antara kedua perlakuan tidak memperlihatkan perbedaan yang nyata.

Sintasan udang selama penelitian memperlihatkan persentase yang tinggi seperti yang tercantum pada Tabel 4.

Sintasan yang dicapai udang pada setiap perlakuan maupun kontrol tidak menunjukkan perbedaan yang nyata $(P>0,05)$. Hal ini berarti bahwa efek pemberian kalsium dalam penelitian ini tidak secara langsung mempengaruhi kesehatan udang. Namun menurut Boyd et al. (2007), kandungan mineral di dalam ransum pakan mampu memberikan sintasan yang lebih tinggi dibandingkan dengan ransum pakan yang tanpa menggunakan mineral. Penelitian mengenai kebutuhan mineral pada udang galah juga dilakukan oleh Adhikari et al. (2007) yang meneliti tentang efek pemberian $\mathrm{CaCO}_{3}$ terhadap sintasan udang tersebut dengan perlakuan berbagai variasi penambahan $\mathrm{CaCO}_{3}$ dalam media pemeliharaan. Pada kadar $\mathrm{CaCO}_{3}$ yang tinggi ( $>228 \mathrm{mg} / \mathrm{L} \mathrm{CaCO}_{3}$ ) ternyata sangat berpengaruh terhadap sintasan dan mengakibatkan penurunan sintasan udang sehingga hanya mencapai sintasan sebesar $10 \%$. Sebaliknya pada kadar yang medium (100 
Tabel 4. Sintasan udang galah (\%) yang dicapai pada setiap perlakuan dengan kadar kalsium karbonat 1,0\%; 3,0\%; 5,0\%; 7,0\%; dan kontrol

Table 4. Survival rate (\%) of each treatment with calcium dosage of $1.0 \%$, $3.0 \%, 5.0 \%, 7.0 \%$, and control

\begin{tabular}{|c|c|c|c|c|}
\hline \multirow{2}{*}{$\begin{array}{c}\text { Perlakuan } \\
\text { Treatment }\end{array}$} & \multicolumn{3}{|c|}{ Sint asan (Survival rate) (\%) } & \multirow{2}{*}{$\begin{array}{c}\text { Rata-rata } \\
\text { Average }\end{array}$} \\
\hline & 1 & 2 & 3 & \\
\hline $1.0 \%$ & 100.0 & 100.0 & 100.0 & $100.0^{\mathrm{a}}$ \\
\hline $3.0 \%$ & 95.0 & 100.0 & 100.0 & $98.3^{\mathrm{a}}$ \\
\hline $5.0 \%$ & 95.0 & 100.0 & 100.0 & $98.3^{a}$ \\
\hline $7.0 \%$ & 100.0 & 100.0 & 100.0 & $98.3^{\mathrm{a}}$ \\
\hline Kontrol (Control) & 95.0 & 100.0 & 95.0 & $98.3^{\mathrm{a}}$ \\
\hline
\end{tabular}

Nilai pada kolom dengan huruf yang sama tidak berbeda nyata $(P>0.05)$

Values in the same column with the same letter are not significantly different $(P>0.05)$

Tabel 5. Kisaran nilai kualitas air pada air media udang selama12 minggu masa pemeliharaan

Table 5. Range of water quality of culture media for 12 weeks grow-out

\begin{tabular}{lc}
\hline Paramet er (Parameter) & Kisaran nilai (Range of value) \\
\hline Suhu air $($ Temperature $)\left({ }^{\circ} \mathrm{C}\right)$ & $27.0 \pm 0.72-30.6 \pm 1.13$ \\
$\mathrm{pH}$ & $6.9 \pm 0.05-8.8 \pm 0.06$ \\
Oksigen terlarut (Dissolved oxygen) $(\mathrm{mg} / \mathrm{L})$ & $6.7 \pm 0.3-8.8 \pm 0.4$ \\
Amonia $($ Ammonia $)(\mathrm{mg} / \mathrm{L})$ & $0.02 \pm 0.003-0.04 \pm 0.004$ \\
Nitrit $($ Nitrite $)(\mathrm{mg} / \mathrm{L})$ & $0.27 \pm 0.08-0.40 \pm 0.085$ \\
Alkalinitas $($ Alkalinity) $(\mathrm{mg} / \mathrm{L})$ & $111.9 \pm 6.8-118.7 \pm 6.7$ \\
\hline
\end{tabular}

$\mathrm{mg} / \mathrm{L} \mathrm{CaCO}_{3}$ ) udang galah dapat mencapai sintasan sebesar $90 \%$. Dengan demikian faktor lingkungan memberikan kontribusi terhadap sintasan udang galah.

Dalam penelitian ini tingginya persentase sintasan pada semua perlakuan ini diduga karena faktor pendukung kelangsungan hidup seperti pakan, kualitas air serta pemeliharaan yang cukup baik. Salah satu parameter yang penting adalah alkalinitas yang mencapai kadar 111,9-118,7 mg/L, kadar ini ternyata mendekati nilai optimum kebutuhan udang akan $\mathrm{CaCO}_{3}$ sehingga sintasan udang yang dicapai relatif tinggi. Data kualitas air dapat dilihat pada Tabel 5.

Kisaran nilai kualitas air seperti suhu, pH, oksigen terlarut, amonia, nitrit, dan alkalinitas pada semua perlakuan masih berada dalam batas yang dapat ditoleransi oleh udang galah.

\section{KESIMPULAN}

Kadar kalsium dalam ransum pakan sangat mempengaruhi laju pertumbuhan harian udang galah. Kadar kalsium yang optimal dalam ransum pakan udang galah adalah sebesar $3,46 \%$.

\section{DAFTAR ACUAN}

Adhikari, S., Chaurasia, V.S., Naqvi A.A., \& Pillai, B.R. 2007. Survival and Growth of Macrobrcahium rosenbergii (de Man). Juvenile in Relation to Calcium Hardness and Bicarbonate Alkalinity. Turkish Journal of Fisheries and Aquatic Sciences, 7: 23-26.

Baron, D.N. 1990. Kapita selekta "Patologi Klinik" (A short text book of chemical pathology) oleh D.N. Baron; alih bahasa, Petrus Andrianto, Johannes Gunawan. Ed. 4. Jakarta: EGC, 201 pp. 
Boyd, C.A., Boyd, C.E., and Rouse, D.B. 2007. Potassium Adsorption by Bottom Soils in Ponds for Inland Culture of Marine Shrimp in Alabama. Journal of the World. Aquaculture Society, 38(1): 85-91.

Cheng, K.M, Hu, C.Q., Liu, Y.N., \& Zheng, S.X. 2005. Dietary magnesium requirement and physiological responses of marine shrimp Litopenaeus vannamei reared in low salinity water. Aquaculture Nutrition, 11 (5): 385-393.

Davis, D.A., Lawrence, A.L., \& Gatlin III, D.M. 1992. Requirement of Penaeus vannamei: A Preliminary Examination of the Dietary Essentiality for Thirteen Minerals. Journal of the World. Aquaculture Society, 23(1): 8-14.

Davis, D.A., Boyd, C.E., \& Saoud, I.P. 2005. Effect of Potassium and Age of Growth and Survival of Litopenaeus vannamei Post Larvae Reared in Inland Low Salinity Well Waters in Alabama. Journal of the World Aqua-culture Society, 36(3): 416-419.

Frence, J.N. 1983. Response of the crayfish Orconectes virilis to experimental acidification of the lake with special reference tomthe importance of calcium. Dalam Goldman,C.R. (Ed.). Freshwater Crayfish V. AVI. Publsh.Comp. Inc., Westport, p. 2545.

Greenway, P. 1974. Calcium Balance at Postmoult stage of the Freshwater Crayfish Austropotamobius pallipes (Lereboullet). J. Exp. Bio., 61: 35-45.

Hepher, B. 1988. Nutrition of Pond Fish. Cambridge University Press. Melbourne Sydney, p. 239-245.

Kompiang, I.P. 1989. Prinsip Dasar Nutrisi. Short Course Budidaya Udang Intensif. Jakarta, 12 hlm.

National Research Council. 1983. Nutrient Requirement of Warm Water Fishes and Shellfish. National Academy of Science. Washington DC, 102 pp.
Pan, Q., Chen, X.Y., Li, F., Bi, Y.Z., \& Zheng, S.X. 2006. Response of juvenile Litopenaeus vannamei to varying levels of calcium phosphate monobasic supplemented to a practical diet. Journal of the World Aquaculture Society, 258: 388-395.

Piliang, W.G. 2000. Nutrisi mineral. Institut Pertanian Bogor. Edisi ke-3. p. 13-38. Saravanan, S., B.S. Kamalam, \&J.S.S. Kumar. 2008. CIFE, Mumbai, India.

Shiau, S.Y. \& Hsieh, J.F. 2001. Dietary potassium requirement of juvenile grass shrimpPenaeus monodon. Fisheries Science, 67(4): 592-595.

Soeharso, D. 1999. Kajian Komposisi dan Struktur Senyawa Mineral dalam Kutikula Macrobrachium rosenbergii dan Penaeus monodon serta Evolusinya Selama Periode Moulting. Phd Thesis, $\mathrm{S}_{3}$ Mathematic and Nature Sciences of Indonesia University.

Surtiati, R.H.S. 2000. Pengaruh Konsentrasi Kalsium Media terhadap Kelangsungan Hidup Ikan Jambal. Program Studi Budidaya Perairan. Faperik. IPB. Bogor, 4 hlm.

Sudjana. 1992. Teknik Analisis Regresi dan Korelasi bagi Para Peneliti. Penerbit TARSITO. Bandung, hlm. 183-188.

Sudjana. 1995. Desain dan Analisis Eksperimen. Edisi IV. Penerbit TARSITO. Bandung, hlm. 292-303.

Ton, F. 1992. Biokimia, Nutrisi dan Metabolisme. UI Press. Jakarta, $258 \mathrm{hlm}$.

Yitnosumarto, S. 1993. Percobaan Perancangan, Analisis dan Interpretasinya. Gramedia Pustaka Utama. Jakarta, $225 \mathrm{hlm}$.

Zaidy, A.B. 2007. Pendayagunaan Kalsium Media Perairan dalam Proses Ganti Kulit dan Konsekuensinya bagi Pertumbuhan Udang Galah (M. rosenbergii). Sekolah Pasca Sarjana IPB.Bogor, $31 \mathrm{hlm}$.

Zonneveld, N., Huisman, E.A., \& Boon, J.H. 1991. Prinsip-prinsip Budidaya Ikan. PT Gramedia Pustaka Utama. Jakarta, $100 \mathrm{hlm}$. 